\title{
Regional Innovation System Development: Comparative Analysis of the Republic of Tatarstan and Volga Federal District Regions
}

\author{
Sadyrtdinov R.R. ${ }^{a}$ \\ Korablev M.Mb \\ Vladimirova S.A.c
}

a b Kazan Federal University, Institute of Management, Economics and Finance, Kazan, 420008, Russia

c Kazan Cooperative Institute, Faculty of Economics and customs affairs, Kazan, 420081, Russia

Email:s_ryslan@mail.ru

Doi:10.5901/mjss.2015.v6n1s3p317

Abstract

The article comprises a set of theoretical and practical suggestions about the development of regional innovation system in the Republic of Tatarstan and realization of regional innovation policy according to strengths and weak of the environment. To understand the opportunities and threats toTatarstan innovation system comparative analysis with Volga federal district regions was hold. As a result the overall ranking of Volga federal district regions was made. Further improvement of Tatarstan innovation system was described by SWOT-analysis.

Keywords: innovation, regional development, Russian Federation, Volga federal district, the Republic of Tatarstan

\section{Introduction}

Innovation, scientific and technological progress in the modern conditions have become the basis for sustainable economic growth of almost all countries of the world, they can better meet the needs of the society in the various types of products and services at substantial savings of natural resources and raw materials, lead to fundamental changes in the technological method production.

Currently one of the most important tasks of government in Russia is the translation of the domestic industry from raw material orientation to the sphere of high technologies. This will dramatically expand the competitive potential of the Russian economy by increasing its comparative advantage in science, education and high technologies and on this basis will have opportunity to use new sources of economic growth and welfare.

Implementation of such a transition at the same time throughout the country is impossible, so it is advisable in the first stage of advancing the promotion of regional innovation development and further replication of their experience. There is no universal set of policy actions to encourage innovation at the regional level. Nevertheless, the common ingredients for a successful regional innovation systems are available. Best practices, mainly applied to the development of individual strategies, the management of the regional innovation system and therealizationof the strategy by local stakeholders.

The Republic of Tatarstan is one of the most developed regions of Russia, and there are all prerequisites for the activation of innovation process, manifested in a significant high-tech manufacturing capacity, the active work of research and education centers, the existing elements of innovation infrastructure. Therefore, at the present time a policy for the development of the innovation system is actively implemented in the Republic of Tatarstan. However, to force the different components of the regional innovation system create expected from the implementation of this policy added value, the government of Tatarstan have to build a mechanism to overcome existing weaknesses and threats to get effective returns on opportunities in the external environment.

\section{Literature Review}

Economists have different opinions concerning the main factors of regional development. Forexample, corporative social responsibility is considered as an important factor of regional development, and the level of economic activity directly influences the indicators of social-economic development $[3,9]$. Investment into fixed basic capital of leading regional 
companies is also the main factor ofattractiveness of the region [4] Marketing approach based on determination of instruments emphasizingthe attractiveness of the region is of particular interest[6].

Innovations play important role in increasing the competitiveness of the regions in the modern globalized world. First innovations were introduced in the model of economic growth in 1957 by Robert Solow. [11] He didn't only prove empirically the impact of innovation on economic growth, but also defined their role as a key, which it remains to this day. A significant contribution to research in this area was made also by R. Lucas [5] and P. Romer [10], who explored the concept of human capital and knowledge dissemination, respectively, emphasizing their relationship with innovation.

The development of innovation at regional level is closely associated with the so-called concept of regional innovation systems (RIS). One of the authors of RIS concept Philipp Cooke determinedRIS as a set of links in innovation chain including companies and organizations which directly generate knowledge, enterprises which use this knowledge and various structures which perform intermediary functions. Regional innovation policy will be efficient only ifregional government coordinate activities of these three components [1,2].To this extent, regional innovation systems research in today's Russia is of particular interest.

\section{Methodology}

The study is based on a comparative analysis of the Republic of Tatarstan and other Volga federal district regionsin the period from 2005 till 2012 year.Set of indicators listed in Table 1 was chosen to compare regional innovation systems.

Table 1. Set of indicators explaining regional innovation system development

\begin{tabular}{|l|l|}
\hline & Indicator name \\
\hline $\mathrm{X} 1$ & Created (developed) advanced production technology in the region \\
\hline $\mathrm{X} 2$ & used advanced production technology in the region \\
\hline $\mathrm{X} 3$ & Expenditure on technological innovation in the region \\
\hline $\mathrm{X} 4$ & Volume of innovative goods, works and services in the region \\
\hline X5 & The total number of elements of innovation infrastructure in the region \\
\hline
\end{tabular}

Firstly for carrying out the ranking of Volga federal district regions on the development of innovative systems average value for the first four indicators is calculated for the period from 2005 year till 2012 year according to the formula:

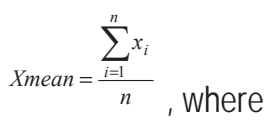

Xmean - the average value of the indicator, $\mathrm{Xi}$ - indicator value in the i year, $\mathrm{n}$ - number of years.

The indicator value X5 is taken cumulatively for the 2012year. Next, absolute values of the indicators are converted into indices for comparison and overall index of regional innovation system development is calculated by the formula:

$$
\text { Rtotal }=\sum_{j=1}^{5} \frac{x_{j}}{x_{\max }} \text {, where }
$$

Rtotal - general index of the regional innovation system development, $X j$ - the value of the indicator "j" of the regional innovation system development,Xmax - maximum value of the indicator " $\mathrm{j}$ " of the regional innovation system development.

The data used by the authors is drawn from statistical yearbooks "Regions of the Russian Federation: socioeconomic indicators" for the period 2005-2012[7].

Further improvement of Tatarstan innovation systemcan be described bySWOT-analysis whichallowes revealing the strengths and weaknesses of the regions' present-day innovation environment, as well as innovation opportunities and threats.

\section{Basic Results}

The total number of elements of the innovation infrastructure (X5) in the regions of the Volga Federal District, including the Republic of Tatarstan, at the end of 2012 year is shown in Fig. 1. [8] 


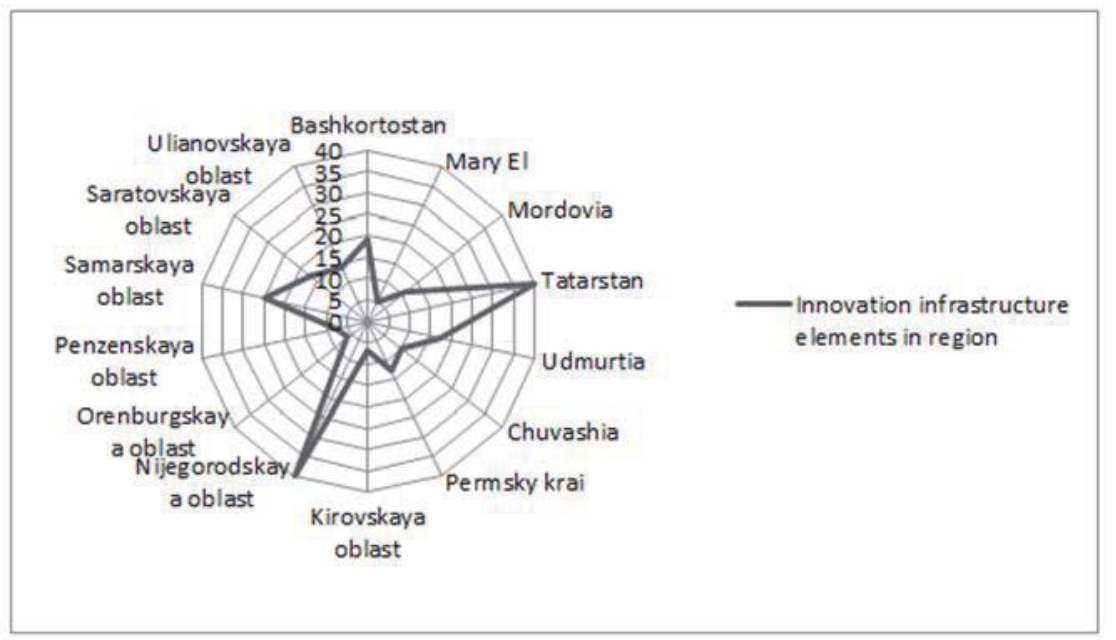

Fig. 1. Innovation infrastructure elements in Volga federal district regions

AsitshowninFig. 1, Tatarstanisoneof the leaders in Volga federal district in the number of innovation infrastructure elements.In Tatarstanthere are 9 technology transfer centers, 9 government bodies for the coordination of innovation, 6 venture capital funds and 2 centers of scientific and technical information, moreover the total number of industrial parks and business incubators - 14 .

The results of innovation systems comparative analysis of the Republic of Tatarstan and Volga federal district regions are presented in Table 2.

Table 2. Innovation systems comparative analysis of the Republic of Tatarstan and Volga federal district regions

\begin{tabular}{|c|c|c|c|c|c|c|c|c|c|c|}
\hline \multirow{2}{*}{ Indicator } & \multicolumn{2}{|c|}{ X1 } & \multicolumn{2}{|c|}{ X2 } & \multicolumn{2}{c|}{ X3 } & \multicolumn{2}{|c|}{ X4 } & \multicolumn{2}{|c|}{ X5 } \\
\cline { 2 - 13 } & \multirow{2}{*}{ unit } & index & unit & index & million rubles & index & million rubles & index & unit & index \\
\hline Rashkortostan & 6 & 0,1 & 5356 & 0,28 & 7533 & 0,38 & 33458 & 0,23 & 19 & 0,47 \\
\hline MaryEI & 3 & 0,05 & 592 & 0,03 & 312 & 0,02 & 1218 & 0,01 & 5 & 0,12 \\
\hline Mordovia & 7 & 0,12 & 1828 & 0,10 & 3484 & 0,18 & 14055 & 0,10 & 11 & 0,27 \\
\hline Tatarstan & 13 & 0,22 & 3103 & 0,17 & 19809 & 1,00 & 145517 & 1,00 & 40 & 1 \\
\hline Udmurtia & 7 & 0,12 & 3755 & 0,20 & 2930 & 0,15 & 8034 & 0,06 & 17 & 0,42 \\
\hline Chuvashia & 6 & 0,1 & 1919 & 0,10 & 2382 & 0,12 & 9906 & 0,07 & 10 & 0,25 \\
\hline Permskykrai & 15 & 0,25 & 4299 & 0,23 & 10924 & 0,55 & 48730 & 0,33 & 13 & 0,32 \\
\hline Kirovskayaoblast & 2 & 0,03 & 2032 & 0,11 & 1411 & 0,07 & 6178 & 0,04 & 7 & 0,17 \\
\hline Nijegorodskayaoblast & 58 & 1 & 18804 & 1,00 & 18110 & 0,91 & 64454 & 0,44 & 40 & 1 \\
\hline Orenburgskayaoblast & 3 & 0,05 & 569 & 0,03 & 3726 & 0,19 & 8096 & 0,06 & 6 & 0,15 \\
\hline Penzenskaya oblast & 10 & 0,17 & 939 & 0,05 & 1768 & 0,09 & 4399 & 0,03 & 8 & 0,2 \\
\hline Samarskaya oblast & 29 & 0,5 & 5310 & 0,28 & 17522 & 0,88 & 127414 & 0,88 & 25 & 0,62 \\
\hline Saratovskaya oblast & 15 & 0,25 & 4443 & 0,24 & 3521 & 0,18 & 10190 & 0,07 & 17 & 0,42 \\
\hline Ulianovskaya oblast & 8 & 0,13 & 1441 & 0,08 & 1191 & 0,06 & 14891 & 0,10 & 14 & 0,35 \\
\hline
\end{tabular}

The overall ranking of innovation system development in Volga federal district regions is shown in Fig. 2. 


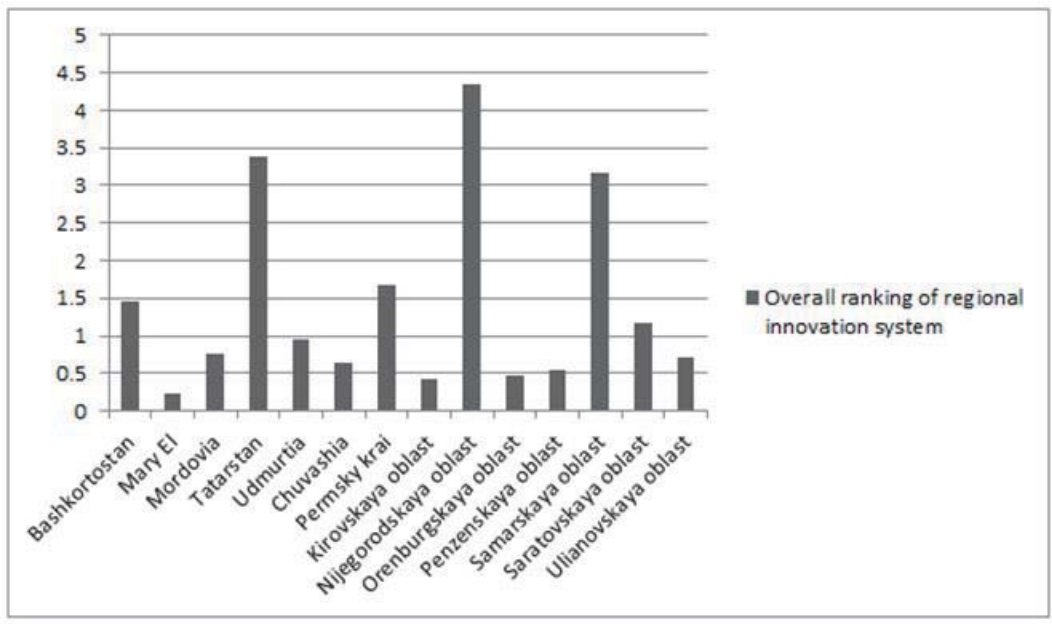

Fig. 2. Overall ranking of innovation system in Volga federal district regions

As seen in Figure 2, the Republic of Tatarstanhas the second rank after the Nijegorodskayaoblast on the development of the innovation system in the overall ranking of the Volga federal district. However, there are challenges in the area of innovation. The manufacturing sector, scientific infrastructure and manpower in Tatarstan have high degree of specialization in relation to the dominant industries. This dependence is constantly reproduced, and each group of participants has no incentives to deviate from this specialization. Process innovations in such regions are widely spread, but product innovations are rare.

In this regard, the application of policy to improve the efficiency of regional innovation system in Tatarstan is very important and requires the immediate adoption of the cardinal, but considered management measures. For this purpose, SWOT-analysis of the Republic of Tatarstan innovation developmentwas conducted.The results are presented in Table 3.

Таблица3. SWOT-analysis of the Republic of Tatarstan innovation development

\begin{tabular}{|c|c|}
\hline Strengths & Weak \\
\hline $\begin{array}{l}\text { 1. The development of the manufacturing industry. } \\
\text { 2. The critical mass of R\&D / higher education } \\
\text { organizations in Kazan and in the whole region. } \\
\text { 3. Oil revenues fill budget resources to support } \\
\text { innovation. } \\
\text { 4. The political will in support of innovation. } \\
\text { 5. A good image of region for russian investors. } \\
\text { 6. Goodqualityoflife. }\end{array}$ & $\begin{array}{l}\text { 1. A very limited number of globally oriented companies. } \\
\text { 2. Reduce in number of students getting scientific and technical } \\
\text { education and the insufficient number of graduates. } \\
\text { 3. Lack of innovation culture in the business and research } \\
\text { communities. } \\
\text { 4. Limited linkages between research institutions and industry. } \\
\text { 5. Limitation of mechanisms for monitoring and evaluation of } \\
\text { innovation policy. }\end{array}$ \\
\hline Opportunities & Threats \\
\hline $\begin{array}{l}\text { 1. Practical transformation of Tatarstanuniversities } \\
\text { to the national research centers. } \\
\text { 2. Increasing the number and quality of applications } \\
\text { for innovative research in Tatarstan. } \\
\text { 3. Access to a large number of markets as a result } \\
\text { of Russia's entry into the World Trade } \\
\text { Organization. } \\
\text { 4. Increase of public funding for innovation }\end{array}$ & $\begin{array}{l}\text { 1. The management and financing of research institutions and } \\
\text { universities at the federal level does not contribute to market- } \\
\text { oriented R\&D. } \\
\text { 2. Federal programs supporting innovations do not provide sufficient } \\
\text { support for market-oriented R\&D and innovation at an early stage } \\
\text { of development. } \\
\text { 3. Weak competition policy at the national level. } \\
\text { 4. Inadequate and unstable protection of intellectual property rights } \\
\text { at the national level. }\end{array}$ \\
\hline
\end{tabular}

\section{Conclusion}

The results of SWOT-analysis together with the regional innovation competitiveness analysis demonstrate that by the present time in the Republic of Tatarstanthere are proper opportunities to foster innovation development and further modernization towards technical and technological re-equipment of key branches, implementation of new technologies and resource saving. 


\section{References}

Cooke, P. and K. Morgan, 1993. The network paradigm: new departures in corporate and regional development. Environment and Planning, 11: 543-564.

Cooke, P., 2001. Regional Innovation Systems, Clusters and the Knowledge Economy, Industrial and Corporate Change, Oxford University Press, 10(4): 945-974.

Glebova, I.S., Rodnyansky, D., Sadyrtdinov, R., Khabibrakhmanova, R. and Yasnitskaya Y. Evaluation of Corporate Social Responsibility of Russian Companies Based on Nonfinancial Reporting // Middle-East Journal of Scientific Research 13 (SocioEconomic Sciences and Humanities): 143-148, 2013.

Glebova, I., Sadyrtdinov, R., and Rodnyansky D. Impact Analysis of Investment Attractiveness of the Republic of Tatarstan on Fixed Investments of its Leading Companies // World Applied Sciences Journal 26(7), 2013, 911-916.

Lucas R. Expectations and Neutrality of Money // Journal of Economic Theory. 1972. Vol. 4, Issue 2, 1972, Pages 103-124

Panasyuk, M.V., Bagautdinova, N.G., Safiullin, L.N., Novenkova, A.Z. Territorial approach to solving the region strategic management problems // World Applied Sciences Journal, 27(13), 2013, 149-153.

Gallyamova, D Cluster policy as a tool of regional economics competitiveness improvement. Economic Annals-XXI, Volume 3-4, Issue 1, 2014, Pages 12-15.

Kinossian, N. (2007). Americanization of Russian cities? Berkeley Planning Journal, 20, pp. 125-128.

Regions of Russia. Socio-economic indicators, 2013.Rosstat. 990 pp.

Official website of Ministry of Economic Development of the Russian Federation(http://economy.gov.ru).

Rodnyansky, D., Sadyrtdinov, R., Zagladina, E. Corporative Social Responsibility and Its Role in Strategy of Social-Economic Development of the Region // Mediterranean Journal of Social Sciences, 5 (12), 2014, 135-139

Romer P. The Problem of Development: A Conference of the Institute for the Study of Free Enterprise Systems// The Journal of Political Economy. 1990. Vol. 98, No. 5, Part 2, pp. S71-S102.

Solow, R. Technical Change and the Aggregate Production Function. // Review of Economics and Statistics. 1957. 39 (3): $312-320$.

Gallyamova D. Kh. Development of Globalization in the Modern Economy // World Applied Sciences Journal 30 (9): 1160-1165, 2014

Nurieva, A.R., Gibadullin, M.Z., Fazlieva, E.P. Stability of interregional trade and economic relations as the factor of competitiveness of territories, World Applied Sciences Journal, Volume 29, Issue 4, 2014, Pages 501-505

Gibadullin, M.Z., Fazlieva, E.P., Nurieva, A.R., Grigoryeva, L.L. Territorial aspects of migration processes in Russia. Mediterranean Journal of Social Sciences, Volume 5, Issue 12, June 2014, Pages 93-96. 